\title{
Vitamin A deficiency and colonic electrogenic absorption and secretion in the rat
}

\author{
H C Nzegwu, R J Levin
}

\begin{abstract}
The effects of vitamin A deficiency on electrogenic transport in the colon were examined in rats made vitamin $A$ deficient at weaning by feeding a vitamin A deficient diet for $\mathbf{4 0}$ days. A pair fed control group was given the same diet but supplemented with soluble vitamin $A$ in their drinking water. The basal and stimulated electrogenic secretory and absorptive functions of the muscle stripped proximal, mid, and distal colon were examined in vitro using the short circuit current (Isc) as the index of net ion transport. A significant increase in the basal and secretory Isc (mainly $\mathrm{Cl}^{-}$ ions) induced by the cholinergic agonist bethanechol was observed in the mid-colon of the vitamin A deficient rats. In the distal colon, however, vitamin A deficiency caused a significant reduction in both the basal and secretory Isc response to bethanechol compared with the vitamin A supplemented pair fed control. Secretory Isc induced by dibutyryl cyclic adenosine monophosphate was not significantly altered by vitamin A deficiency. The condition abolished the response of the distal colon to luminal amiloride $(0 \cdot 1 \mathrm{mmol} / \mathrm{l})$. Thyroid hormone induced reduction in the distal colonic response to aldosterone is implicated in this lack of response. This is the first experimental linkage between vitamin A action, the thyroid hormone and aldosterone on colonic function. The colonic changes induced by vitamin $A$ deficiency, namely hypersecretion and a reduced electrogenic distal absorptive function, together with the previously described small intestine hypersecretion may be the underlying basis for the diarrhoea observed in human and animal vitamin A deficiency.
\end{abstract}

Diarrhoea is a well known accompaniment of vitamin A deficiency in humans ${ }^{1}$ and in primates. ${ }^{2}$ Its cause has not been established unequivocally despite numerous field studies. ${ }^{3}$ Because of difficulties in carrying out controlled human experiments, an investigation into the effects of vitamin A deficiency on the secretory and absorptive functions of the small and large intestine in the rat was undertaken. We have reported previously that vitamin A deficiency increases secretory function in the rat small intestine. ${ }^{+}$The present study examines the secretory and absorptive functions of the rat proximal, mid, and distal colon in vitamin A deficiency. The results show that vitamin A deficiency induced specific changes in the colonic response to both secretory and absorptive stimulations. These changes, together with those observed in the small intestine, ${ }^{+}$could be the underlying basis of the alimentary disorder leading to the diarrhoeal state in the human. An interesting feature of the study is the putative involvement of the thyroid hormones in the action of vitamin $\mathrm{A}$ and aldosterone on the induction of electrogenic $\mathrm{Na}^{+}$absorption in the distal colon.

\section{Methods}

ANIMAL GROUPS

Weanling, 3 week old, male albino rats of the Sheffield University strain (weight $60-80 \mathrm{~g}$ ) were divided into six groups (see Table I for summary). Group 1 was fed a commercially supplied vitamin A deficient diet (diet ssDii) for $\mathbf{4 0}$ days ad lib and had free access to water. The diet contained casein (15\%), icing sugar $(25 \%)$, rice starch (35\%), safflower oil (10\%), Solkafloc $(10 \%)$, and a mixture of vitamins (excluding vitamin A) and essential minerals (5\%). The diet was quoted as having a retinol concentration of $0 \mathrm{mg} / \mathrm{kg}$. The food intake of the rats was measured daily and has been published previously. ${ }^{+}$Groups 2 and 3 were pair fed (with group 1) on the vitamin A deficient diet but had a soluble preparation of vitamin A (Rovimix A, type $500 \mathrm{~W}$ ) in their drinking water. The intake of group 2 was approximately 80 IU vitamin $\mathrm{A} /$ day, while that of group 3 was 240 IU vitamin A/ day. Group 4 was pair fed (with group 1) using the standard diet (diet CRM, containing 1500 IU vitamin $\mathrm{A} / \mathrm{kg}$ ). Group 5 comprised age matched controls fed the standard diet CRM ad lib. Group 6 (acutely undernourished) comprised age matched controls fed one third (approximately $8 \mathrm{~g}$ ) of the average adult rat daily food (diet CRM) intake/day for nine days. All the rats were housed in plastic cages in a room maintained at $20(1)^{\circ} \mathrm{C}$ with the humidity kept at $72 \%$. The lights were switched on from 5.30 am until 6.30 pm.

\section{HYPOTHYROID RATS}

Rats were made hypothyroid by allowing them to drink a solution of $0.5 \mathrm{mmol} / \mathrm{l}$ 6-n-propyl-2thiouracil ad lib for 28 days with standard diet CRM provided ad lib. These hypothyroid rats were divided into three groups (see Table I). Group A was fed ad lib, group B was acutely undernourished for nine days by feeding them one third (approximately $8 \mathrm{~g}$ ) of the average adult rat daily food (diet CRM) intake/day. The reduced intake was started on the 19th day and maintained until the 28th day of the induction of hypothyroidism. Group C was acutely undernourished, identically to group $B$, but received a daily subcutaneous injection of $L$-thyroxine
H C Nzegwu

R J Levin

Correspondence to: Dr R J Levin, Department of Biomedical Science, University of Sheffield, S10 2TN.

Accepted for publication 9 September 1991 
TABLE I Diet and experimental treatment of the various animal groups used

\begin{tabular}{|c|c|}
\hline Group & Diet and treatment \\
\hline 1 & Vitamin A deficient diet (ssDii) fed ad lib+ad lib water. \\
\hline 2 & $\begin{array}{l}\text { Vitamin A deficient diet (ssDii), pair fed according to group } 1 \text { intake }+80 \text { IU vitamin A intake } \\
\text { from drinking water (ad lib). }\end{array}$ \\
\hline 3 & $\begin{array}{l}\text { Vitamin A deficient diet (ss Dii), pair fed according to group } 1 \text { intake + } 240 \text { IU vitamin A } \\
\text { intake from drinking water (ad lib). }\end{array}$ \\
\hline $\begin{array}{l}4 \\
5\end{array}$ & $\begin{array}{l}\text { Standard diet CRM (Labsure), pair fed according to group } 1 \text { intake+water ad lib. } \\
\text { Age matched controls for group } 1 \text { fed standard diet CRM ad lib+water ad lib. }\end{array}$ \\
\hline 6 & $\begin{array}{l}\text { Age matched controls for group } 1 \text { fed approximately } 33 \%(8 \mathrm{~g} / \text { day) of normal rat daily food } \\
\text { intake for nine days + water ad lib (acutely undernourished). }\end{array}$ \\
\hline A & $\begin{array}{l}\text { Standard diet CRM fed ad lib }+0.5 \mathrm{mmol} / 1 \text { 6-n-propyl-2-thiouracil in drinking water (ad lib) } \\
\text { for } 28 \text { days. }\end{array}$ \\
\hline B & $\begin{array}{l}\text { Standard diet CRM fed ad lib }+0.5 \mathrm{mmol} / \mathrm{l} \text { 6-n-propyl-2-thiouracil in drinking water for } 19 \\
\text { days, then fed } 8 \mathrm{~g} \text { diet CRM per day for nine days with propyl-thiouracil in drinking water (ad } \\
\text { lib). }\end{array}$ \\
\hline C & $\begin{array}{l}\text { Identical dietary and fluid intakes as group B but also given injections of L-thyroxine ( } 5 \mu \mathrm{g} / \\
100 \mathrm{~g} \text { bwt, sc) per day for the last nine days when on the reduced food intake. }\end{array}$ \\
\hline
\end{tabular}

(5 $\mu \mathrm{g} / 100 \mathrm{~g}$ bodyweight/day) throughout the nine days of hypothyroid induction and acute undernutrition. Evidence of induced hypothyroidism was shown by the significantly larger thyroid gland dry weight in the thiouracil fed rats $(15.6(1.4) \mathrm{mg}(\mathrm{n}=6))$ when compared with either the control conventional ad lib fed rats (group 5; $8.2(0.6) \mathrm{mg}(\mathrm{n}=6), \mathrm{p}<0.001)$ or the hypothyroid rats receiving $\mathrm{L}$-thyroxine (group C; $7 \cdot 0(0.6) \mathrm{mg}(\mathrm{n}=6), \mathrm{p}<0.001)$.

\section{IN VITRO PREPARATION}

Rats were anaesthetised with intraperitoneal pentobarbitone (Sagatal, $60 \mathrm{mg} / \mathrm{kg}$ bodyweight). On achieving surgical anaesthesia, a mid-line abdominal incision was made and the colon located. Segments (3 $\mathrm{cm}$ in length) identified as the proximal colon (starting immediately adjacent and aboral to the caecum), mid-colon (starting approximately $6 \mathrm{~cm}$ distal to the caecum), and distal colon (starting approximately $13 \mathrm{~cm}$ distal to the caecum and terminating at the distal colonic lymph node), were removed, rinsed with prewarmed saline, and then stripped of their external muscle. The segment was cut open along the mesenteric border and mounted as a flat sheet between two identical chambers as described previously. ${ }^{5}$ The exposed tissue area was approximately $2 \mathrm{~cm}^{2}$. The segments were incubated at $38^{\circ} \mathrm{C}$ in bicarbonate saline, gassed with $95 \% \mathrm{O}_{2}, 5 \% \mathrm{CO}_{2}$. The tissue potential difference ( $\mathrm{pd}$ in $\mathrm{mV}$ ), tissue resistance $\left(R\right.$, in ohms $/ \mathrm{cm}^{2}$ serosal area), and calculated short circuit current (Isc in $\mu \mathrm{A} / \mathrm{cm}^{2}$ serosal area) were obtained as described previously. ${ }^{5}$ The secretory function was assessed in both the basal condition (Isc in the absence of secretagogue addition) and after the addition of

TABLE II Basal Isc $\left(\mu \mathrm{A} / \mathrm{cm}^{2}\right.$ serosal area $)$ of stripped proximal, mid, and distal colon from various nutritional groups. Results are given as mean (SEM) with the number of rats shown in square brackets.

\begin{tabular}{|c|c|c|c|}
\hline \multirow[t]{2}{*}{ Group } & \multicolumn{3}{|c|}{ Basal colonic Isc $\left(\mu \mathrm{A} / \mathrm{cm}^{\prime}\right)$} \\
\hline & Proximal & Mid & Distal \\
\hline $\begin{array}{l}1 \\
2 \\
3 \\
4 \\
5\end{array}$ & $\begin{array}{c}81(5)[21]^{\mathrm{A}} \\
87(12)[8]^{\mathrm{h}} \\
85(5)[17]^{\mathrm{a}} \\
160(11)[20]^{\mathrm{A}} \\
84(3)[123]^{\mathrm{k}}\end{array}$ & $\begin{array}{c}91(6)[21]^{\prime} \\
108(10)[8]^{k} \\
90(5)[17]^{\mathrm{h}} \\
99(10)[20]^{\prime} \\
71(2)[117]^{\prime}\end{array}$ & $\begin{array}{c}52(5)[21]^{\mathrm{k}} \\
94(17)[8]^{\prime} \\
87(8)[17]^{\prime \prime \prime} \\
152(17)[20]^{\mathrm{n}} \\
47(2)[112]^{\prime \prime}\end{array}$ \\
\hline
\end{tabular}

Statistical comparison used the Kruskal-Wallis ANOVA followed by Conover's multiple $t$ test to identify the statistically significant values $\mathrm{k} v \mathrm{l}=\mathrm{p}<0.05$ while the following are significant at

$\mathrm{p}<0.001$ : a $v \mathrm{~d}, \mathrm{~b} v \mathrm{~d}, \mathrm{c} v \mathrm{~d}, \mathrm{~d} v \mathrm{e}, \mathrm{f} v \mathrm{j}, \mathrm{g} v \mathrm{j}, \mathrm{i} v \mathrm{j}, \mathrm{k} v \mathrm{~m}, \mathrm{k} v \mathrm{n}, 1 v_{0}$ $\mathrm{m} v 0, \mathrm{n} v 0$. the stable muscarinic agonist bethanechol or dibutyryl cyclic adenosine monophosphate (cAMP) (monitored as the $\Delta \mathrm{Isc}_{\max }=$ maximum Isc-basal Isc). The electrogenic $\mathrm{Na}^{+}$transfer of the segment was assessed by the maximum decrease in the stable basal Isc $\left(-\Delta \mathrm{Isc}_{\max }\right)$ after the mucosal addition of amiloride $(0 \cdot 1 \mathrm{mmol} / \mathrm{l})$.

\section{PLASMA VITAMIN A ESTIMATION}

The plasma vitamin $A$ concentration of the various nutritional groups was estimated as described previously. ${ }^{+}$

\section{MATERIALS AND DIETS}

All chemicals were purchased from Sigma Chemical Company Ltd, Poole, England. The vitamin A deficient diet (ssDii) was purchased from SDS Diet Ltd, England, and the normal control diet (CRM) from Labsure, London. The soluble vitamin $\mathrm{A}$ added to the drinking water (Rovimix A, type 500W) was a gift from Roche Products Ltd, Welwyn Garden City, Herts, England.

\section{STATISTICAL ANALYSIS}

Results are shown as mean (SEM). Statistical comparisons were by paired or unpaired Student's $t$ test as appropriate with $0.05 \%$ as the level of significance. When multiple comparisons were needed, the Kruskal-Wallis analysis of variance was used followed by Conover's multiple $t$ test to delineate specific differences. ${ }^{6}$

\section{Results}

\section{FOOD INTAKE}

A detailed analysis of the food intake of the various nutritional groups has been reported. ${ }^{+}$ A point to note is that the diet CRM pair fed rats (group 4) represent a chronically undernourished group when compared with the CRM ad lib fed rats (group 5). For example, on day 40, group 4 rats ate only $9 \mathrm{~g}$ food/day while those in group 5 averaged $24 \mathrm{~g} /$ day. Group 4 rats would have an average daily vitamin $A$ intake of $135 \mathrm{IU}$, (based on $1500 \mathrm{IU}$ vitamin $\mathrm{A} / \mathrm{kg}$ diet), while group 5 would have an intake of $360 \mathrm{IU} /$ day.

\section{VITAMIN A PLASMA CONCENTRATIONS}

Estimations of the plasma vitamin A concentration in the various nutritional groups $(1-5)$ have been reported. ${ }^{+}$The plasma vitamin A concentration of the vitamin A deficient rats (group 1) was the lowest $(22.4(5.6) \mu \mathrm{g} / \mathrm{dl}(\mathrm{n}=14))$. The plasma vitamin A concentration in the vitamin A deficient rats supplemented with 80 IU vitamin A/day (group 2) was not significantly different from that seen in group $1(35.5(3.6) \mu \mathrm{g} / \mathrm{dl}$ $(n=6), p>0 \cdot 05)$. Those supplemented with 240 IU vitamin A/day (group 3 ) had a plasma concentration of $79.2(7 \cdot 7) \mu \mathrm{g} / \mathrm{dl} \quad(\mathrm{n}=11)$, which was significantly greater than that of group 1 $(\mathrm{p}<0.001)$. Furthermore, the plasma vitamin A concentration in group 3 was not significantly different from that in the rats pair fed the CRM 
TABLE III Maximun Isc $\left(\mu A / \mathrm{cm}^{2}\right.$ serosal area $)$ induced by $1 \mathrm{mmol} / \mathrm{l}$ serosal bethanechol in stripped proximal, mid, and distal colon from various nutritional groups. Results are given as mean (SEM) with the number of rats shown in square brackets

\begin{tabular}{|c|c|c|c|}
\hline \multirow[t]{2}{*}{ Group } & \multicolumn{3}{|c|}{ Colonic $\Delta I s c_{\max }\left(\mu \mathrm{A} / \mathrm{cm}^{2}\right)$} \\
\hline & Proximal & Mid & Distal \\
\hline $\begin{array}{l}1 \\
2 \\
3 \\
4 \\
5\end{array}$ & $\begin{array}{l}173(12)[11]^{a} \\
156(6)[13]^{\mathrm{h}} \\
143(9)[6]^{\mathrm{c}} \\
218(13)[8]^{\mathrm{A}} \\
89(9)[23]^{\mathrm{c}}\end{array}$ & $\begin{array}{c}225(11)[11]^{\prime} \\
258(17)[8]^{\mathrm{k}} \\
118(12)[6]^{\mathrm{h}} \\
257(13)[8]^{\mathrm{t}} \\
85(6)[28]^{\prime}\end{array}$ & $\begin{array}{c}62(8)[11]^{\mathrm{k}} \\
50(7)[8]^{1} \\
132(9)[6]^{\mathrm{m}} \\
66(8)[7]^{\mathrm{n}} \\
32(3)[35]^{\mathrm{N}}\end{array}$ \\
\hline
\end{tabular}

Statistical comparison used the Kruskal-Wallis ANOVA followed by Conover's multiple $t$ test to identify the statistically significant values. The following are significant at $\mathrm{p}<0.05 ; \mathrm{a} v \mathrm{~d}, \mathrm{~h} v \mathrm{j}$; the following are significant at $\mathrm{p}<0.01: \mathrm{b} v \mathrm{~d}, \mathrm{c} v \mathrm{e}$; the following ar significant at $\mathrm{p}<0.001$ : a $v \mathrm{e}, \mathrm{b} v \mathrm{e}, \mathrm{c} v \mathrm{~d}, \mathrm{~d} v \mathrm{e}, \mathrm{f} v \mathrm{~h}, \mathrm{f} v \mathrm{j}, \mathrm{g} v \mathrm{~h}$ $\mathrm{g} v \mathrm{j}, \mathrm{h} v \mathrm{i}, \mathrm{i} v \mathrm{j}, \mathrm{k} v \mathrm{~m}, \mathrm{k} v \mathrm{o}, \mathrm{l} v \mathrm{~m}, \mathrm{~m} v \mathrm{n}, \mathrm{m} v \mathrm{o}, \mathrm{n} v \mathrm{o}$

diet (group 4, $99.6(6 \cdot 0) \mu \mathrm{g} / \mathrm{dl}(\mathrm{n}=11)$ ) and the age matched rats fed the diet CRM ad lib (group $5,92 \cdot 7(8 \cdot 0) \mu \mathrm{g} / \mathrm{dl}(\mathrm{n}=8))$.

\section{COLONIC BIOELECTRIC PROPERTIES}

The basal pd and $R$ of the vitamin A deficient rats (group 1) were not significantly different in the three colonic segments from their pair fed controls (groups 2 and 3) and have not thus been shown. The basal Isc of the various groups, however, showed differences (Table II). The basal Isc of the proximal colon from the vitamin A deficient rats (group 1) was highly significantly lower than that of group 4 rats $(-75 \%$, $\mathrm{p}<0.001$, while in the mid-colon the basal Isc of the group 1 rats was significantly greater than that of group 5 rats $(+30 \%, p<0.001)$. In the distal colon, the basal Isc of group 1 rats was significantly less than that in group $2(-45 \%$, $\mathrm{p}<0.05)$, group $3(-40 \%, \mathrm{p}<0.001)$, and group $4(-66 \%, \mathrm{p}<0 \cdot 001)$.

SECRETORY CURRENTS INDUCED BY BETHANECHOL Secretory currents in the stripped proximal, mid, and distal colon induced by serosal bethanechol are shown in Table III. The time

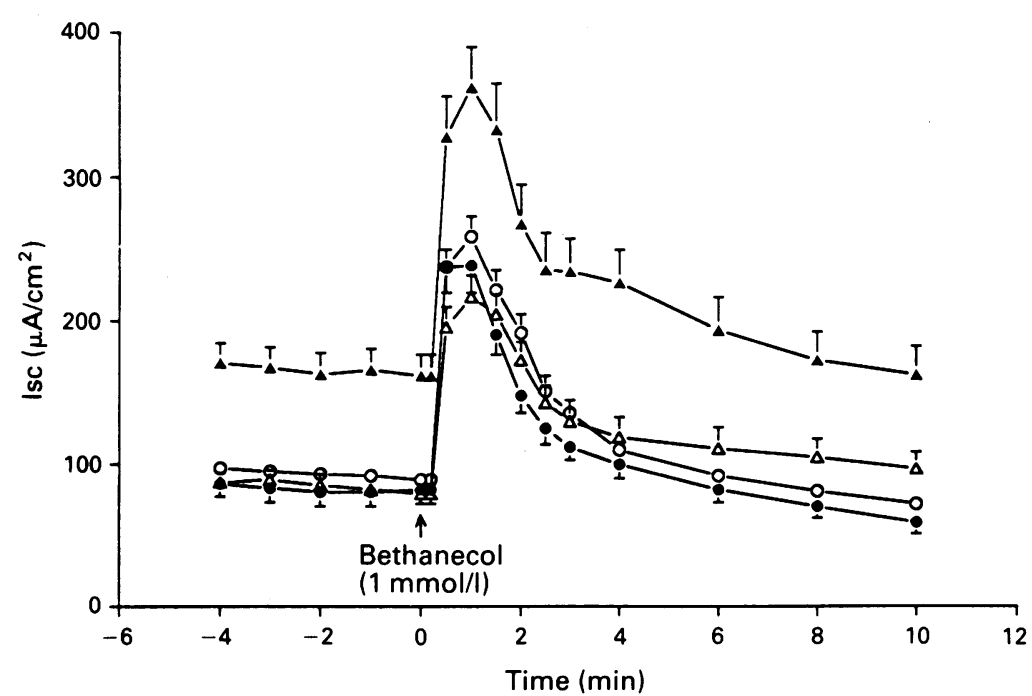

Figure 1: Time course of the short circuit current (Isc) response of stripped proximal colon to the serosal addition of bethanechol in group 1 (vitamin $A$ deficient) $(\bigcirc)$; group 2 (pair fed vitamin A supplemented, 80 IU/rat/day)(O); group 3 (pair fed vitamin A supplemented, 240 IU/rat/ day) $(\triangle)$; and group 4 (pair fed CRM diet) $(\Delta)$ rats. Results are plotted as mean $(S E M)$ representing at least eight animals.
TABLE IV Maximum $\Delta I s c\left(\mu A / \mathrm{cm}^{2}\right.$ serosal area) induced by $1 \mathrm{mmol} / \mathrm{l}$ serosal dibutyryl cyclic adenosine monophosphate in stripped proximal, mid, and distal colon from various nutritional groups. Results are given as mean (SEM) with the number of rats shown in square brackets

\begin{tabular}{llll}
\hline Group & \multicolumn{4}{l}{ Colonic $\Delta I s c_{\text {max }}\left(\mu A / \mathrm{cm}^{2}\right)$} \\
\cline { 2 - 4 } & Proximal & Mid & Distal \\
\hline 1 & $58(4)[10]^{\mathrm{a}}$ & $122(10)[10]^{\mathrm{c}}$ & $65(8)[10]^{\mathrm{\prime}}$ \\
3 & $57(6)[11]^{\mathrm{h}}$ & $104(8)[11]^{\mathrm{h}}$ & $71(11)[11]^{\mathrm{\prime}}$ \\
4 & $62(14)[12]^{\mathrm{c}}$ & $88(12)[12]^{\mathrm{k}}$ & $38(5)[12]^{\mathrm{k}}$ \\
5 & $40(2)[8]^{\mathrm{a}}$ & $80(8)[10]^{\mathrm{h}}$ & $41(4)[8]^{1}$ \\
\hline
\end{tabular}

Statistical comparison used the Kruskal-Wallis ANOVA followed by Conover's multiple $t$ test to identify the statistically significant values. The following are significant at $\mathrm{p}<0.05: \mathrm{b} v \mathrm{~d}, \mathrm{e} v \mathrm{~g}, \mathrm{j} v \mathrm{l}$; a $\mathrm{p}<0.02$ : i $v \mathrm{l}$; at $\mathrm{p}<0.01$ : a $v \mathrm{~d}, \mathrm{e} v \mathrm{~h}, \mathrm{i} v \mathrm{k}, \mathrm{j} v \mathrm{k}$.

course profiles for this response are shown in Figure 1 for the proximal colon.

Comparing the vitamin A deficient rats (group 1) with the vitamin A deficient rats supplemented with vitamin A (group 3), a significantly raised $\Delta \mathrm{Isc}_{\max }$ was seen in the mid-colon of group 1 rats $(+91 \%, p<0 \cdot 001)$. In contrast, the distal colon had a greatly reduced $\Delta \mathrm{Isc}_{\max }$ in the vitamin $\mathrm{A}$ deficient rats compared with group 3 $(-53 \%, \mathrm{p}<0.001)$. When group 4 rats were compared with group 1 rats, a significantly raised secretory $\Delta \mathrm{Isc}_{\max }$ was seen only in the proximal colon $(+26 \%, \mathrm{p}<0.05)$. In comparison with group 5 rats (age matched controls fed normal diet), group 1 showed a significantly raised $\Delta \mathrm{Isc}_{\max }$ in the proximal $(+94 \%, \mathrm{p}<0.001)$, mid $(+164 \%, \mathrm{p}<0.001)$, and distal colon $(+94 \%$, $\mathrm{p}<0.001)$.

SECRETORY CURRENTS INDUCED BY DIBUTYRYL-

CAMP

Secretory currents induced by dibutyryl-cAMP in the stripped proximal, mid, and distal colon are shown in Table IV. Time course profiles for this response are shown in Figure 2 for the proximal colon. The $\Delta \mathrm{Isc}_{\max }$ 's of the vitamin $\mathrm{A}$ deficient rats (group 1) of all segments were not significantly different from those of the vitamin A supplemented pair fed rats (group 3). However, when compared with the diet CRM pair fed rats (group 4), the $\Delta I \mathrm{Isc}_{\max }$ of group 1 rats showed a significant increase in the mid $(+39 \%$, $\mathrm{p}<0.05)$ and distal colon $(+71 \%, \mathrm{p}<0.001)$. When group 1 was compared with group 5 , a significantly raised $\Delta \mathrm{Isc}_{\max }$ was seen in the proximal $(+45 \%, \mathrm{p}<0.01), \mathrm{mid}(+53 \%$, $\mathrm{p}<0.01)$, and distal colon $(+59 \%, \mathrm{p}<0.02)$.

DISTAL COLONIC RESPONSE TO AMILORIDE

The vitamin A deficient rats (group 1) had a reduced food intake when compared with the normal diet CRM fed rats (group 5). In this respect they could be regarded as similar to chronically undernourished rats. ${ }^{+}$Rats in this condition, when compared with fed controls, show an increased basal Isc in the distal colon that is inhibited by amiloride addition.? Consequently, the basal Isc of the distal colons of the group 1 rats were expected to exhibit the typical response to amiloride $(0.1 \mathrm{mmol} / \mathrm{l})$ created by chronic undernourishment. The distal colons from the vitamin A deficient rats, however, did not show this decrease in their basal Isc on the 
addition of amiloride (Fig 3). The distal colons from groups 2 and 3 (Table I) had basal Iscs greater than those of vitamin $\mathrm{A}$ deficient rats (group 1) ( $+118 \%, \mathrm{p}<0.001$ and $+154 \%$, $\mathrm{p}<0.001$ respectively). The addition of mucosal amiloride $(0.1 \mathrm{mmol} / \mathrm{l})$ in groups 2 and 3 instantly reduced their raised basal Isc by $-18 \%$ and $-23 \%$ respectively (both significant at $\mathrm{p}<0.05$, paired $t$ test, Fig 3). The distal colon from the CRM pair fed rats (group 4) had a basal Isc greatly increased above that of the vitamin $A$ deficient rats (group 1) $(+432 \%, p<0.001)$. It responded to mucosal amiloride with the typical instant decrease in basal Isc $(-69 \%, p<0.001)$ observed in chronic undernutrition (Fig 3). Neither the proximal nor mid-colon showed any significant response to amiloride. This agrees with previous findings with conventional rats fed diet CRM ad lib (group 5) (Nzegwu and Levin, unpublished results).

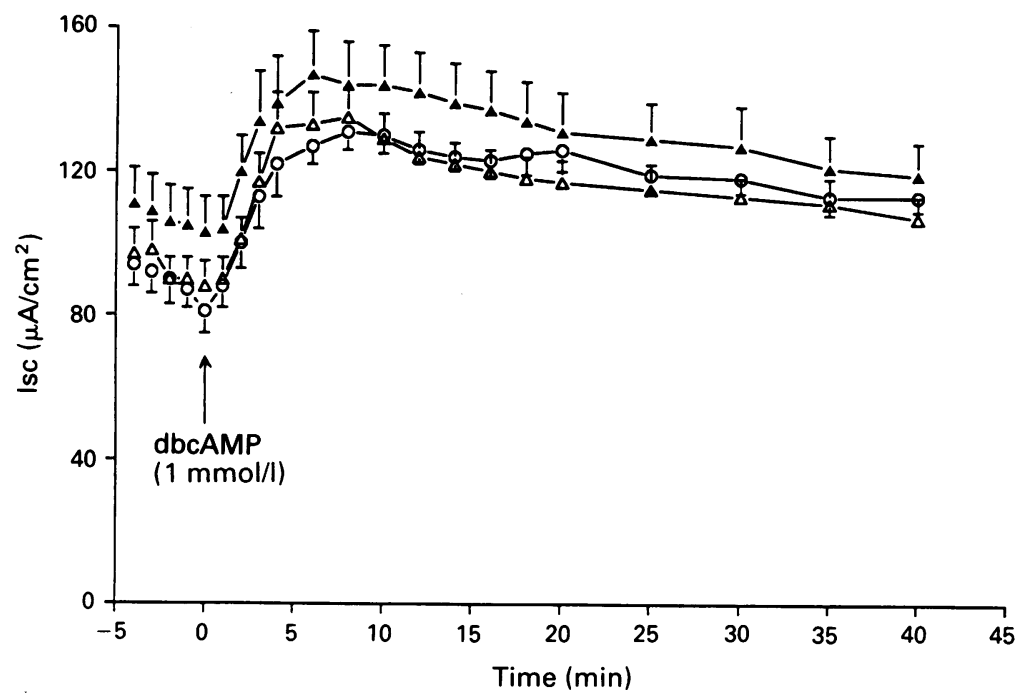

Figure 2: Time course of the short circuit current (Isc) response of stripped proximal colon to the serosal addition of dibutyryl cyclic adenosine monophosphate (dbcAMP) in group 1 (vitamin $A$ deficient) $(\bigcirc)$; group 3 (pair fed vitamin $A$ supplemented, 240 IU/rat/day) $(\triangle)$; and group 4 (pair fed CRM diet) ( $\mathbf{\Delta})$ rats. Results are plotted as mean $(S E M)$ representing at least 10 animals.

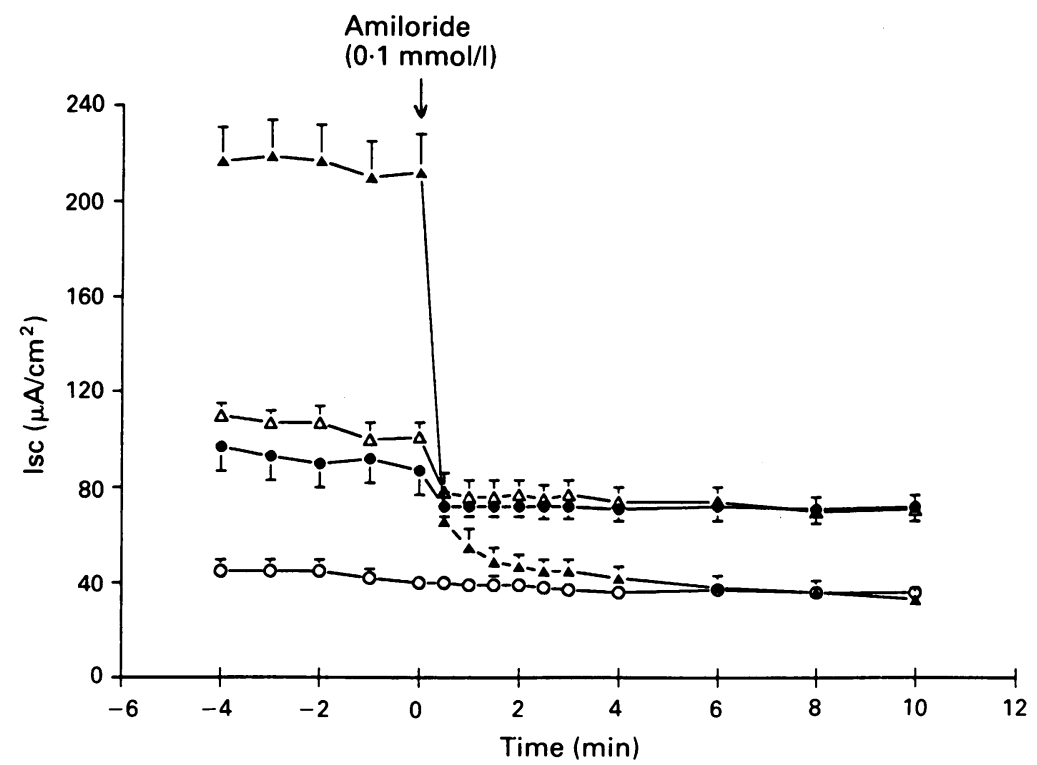

Figure 3: Time course of the short circuit current (Isc) response of stripped distal colon to the mucosal addition of amiloride in group 1 (vitamin $A$ deficient) $(O)$; group 2 (pair fed vitamin $A$ supplemented, 80 IU/rat/day)(O); group 3 (pairfed vitamin A supplemented, 240 IU/rat/day) $(\triangle)$; and group 4 (pair fed CRM diet) ( $\Delta$ ) rats. Results are plotted as mean (SEM) representing at least eight animals.
EFFECT OF HYPOTHYROIDISM ON DISTAL COLONIC TRANSPORT FUNCTION

Vitamin A deficient rats have a raised plasma level of thyroid hormones, ${ }^{89}$ because of their reduced peripheral cellular penetration and metabolism. The peripheral tissue thyroid deficiency may thus create a 'hypothyroid state' in the distal colon which is known to depress the action of aldosterone on the induction of electrogenic $\mathrm{Na}^{+}$transport. ${ }^{10}$ The possibility that this occurred was examined using a group of conventional adult hypothyroid rats and hypothyroid rats made acutely undernourished.

In the hypothyroid acutely undernourished (nine days) rats (group B), the distal colon had a significantly lower basal Isc in contrast to group 6 , where a greatly raised basal Isc typical of acutely undernourished (nine days) conventional rats was found (Table $V$ ). The basal Isc of the ad lib fed hypothyroid rats (Group A), (20 (5) $\mu \mathrm{A} /$ $\mathrm{cm}^{2}(\mathrm{n}=8)$ ) was not significantly different from that of the conventional ad lib fed control rats (group 5), $\left(30(6) \mu \mathrm{A} / \mathrm{cm}^{2}(\mathrm{n}=8)\right)$. The basal Isc of the ad lib fed (group A) and acutely undernourished (nine days) hypothyroid rats (group B) did not show any significant response to mucosal amiloride (Fig 4), a result similar to the lack of response seen in the vitamin A deficient rats (group 1, Fig 3). The hypothyroid acutely undernourished rats receiving L-thyroxine (group C, see methods) not only had a raised basal Isc, similar to the conventional distal colonic response to acute undernutrition (Table IV), but the raised basal Isc also responded to mucosal amiloride with an instantaneous reduction $(-73 \%, \mathrm{p}<0.001$, Fig 4).

\section{Discussion}

VITAMIN A DEFICIENCY AND CONTROL GROUPS This study examined the effects of vitamin A deficiency on the bioelectric properties and electrogenic secretory and absorptive transport of the proximal, mid, and distal colon in vitro. Although several control groups (groups 2-5) were used, the vitamin A supplemented groups 2 and 3 were the direct experimental controls for the vitamin A deficient rats (group 1). However, on analysis of the data, the plasma vitamin A concentration of the $80 \mathrm{IU}$ vitamin A supplemented pair fed rats (group 2) was not significantly different from that of the vitamin A deficient group 1. This vitamin intake was not enough to normalise the vitamin A status of the

TABLE V Basal Isc $\left(\mu \mathrm{A} / \mathrm{cm}^{2}\right.$ serosal area) of stripped distal colon from various nutritional groups. Results are given as mean $(S E M)$ with the number of rats shown in square brackets

\begin{tabular}{lr}
\hline & $\begin{array}{r}\text { Basal Isc } \\
\left(\mu A / \mathrm{cm}^{2}\right)\end{array}$ \\
\hline $\begin{array}{l}\text { Group 5 (ad lib) } \\
\text { Group 6 (nine days acutely undernourished) }\end{array}$ & $\begin{array}{r}30(4)[8]^{\circ} \\
\text { Hypothyroid fed ad lib (group A) }\end{array}$ \\
$\begin{array}{l}\text { Nine days acutely undernourished (group B) made } \\
\text { hypothyroid }\end{array}$ & $20(5)[8]^{\circ}$ \\
$\begin{array}{l}\text { Nine days acutely undernourished (group C) } \\
\text { receiving L-thyroxine (5 } \mu \text { g/100 g bwt/day }\end{array}$ & $8(2)[8]^{\prime \prime}$ \\
\hline
\end{tabular}

Statistical comparisons used the Kruskal-Wallis ANOVA

followed by Conover's multiple $t$ test to identify the statistically significant values. The following are significant at $\mathrm{p}<0.05: \mathrm{c} v \mathrm{~d}$, $\mathrm{c} v \mathrm{e}, \mathrm{d} v \mathrm{e}$ and at $\mathrm{p}<0.001: \mathrm{a} v \mathrm{~b}, \mathrm{a} v \mathrm{~d}, \mathrm{~b} v \mathrm{c}, \mathrm{b} v \mathrm{~d}$ 


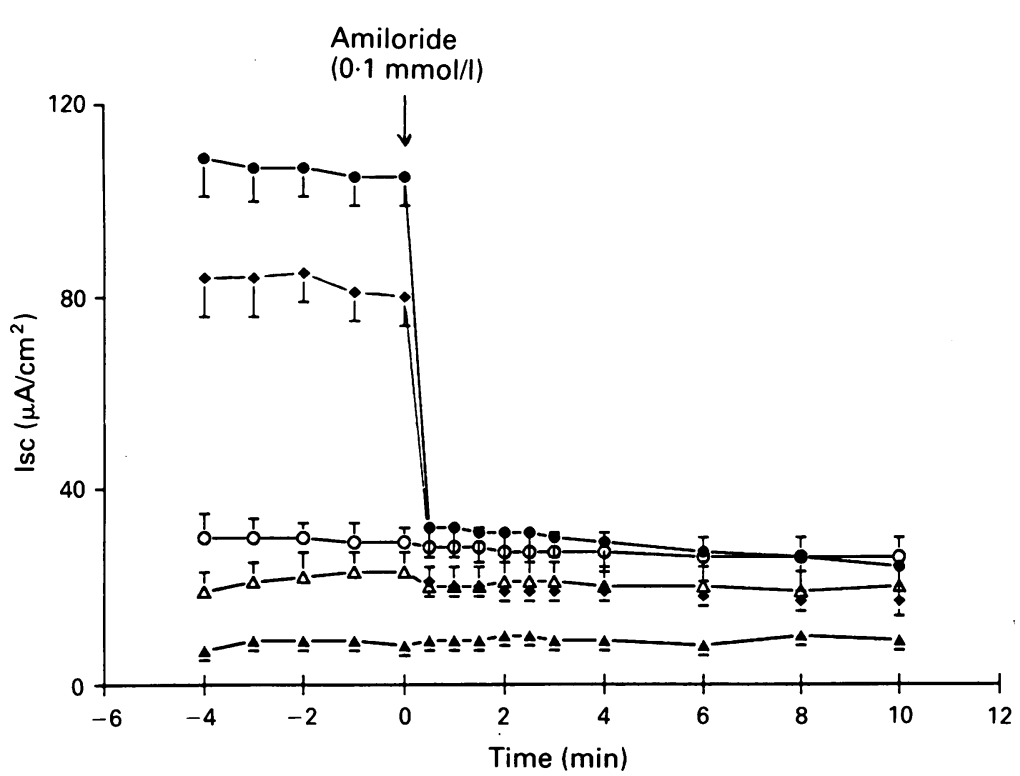

Figure 4: Time course of the short circuit current (Isc) response of stripped distal colon to the mucosal addition of amiloride in group 5 (conventional rats fed ad lib) (O); group 6 (conventional rats acutely undernourished (nine days)) (O); group $A$ (hypothyroid rats, fed ad lib) ( $\triangle$ ); group $B$ (hypothyroid rats acutely undernourished (nine days)) $(\boldsymbol{\Delta})$; and group $C$

(hypothyroid rats acutely undernourished and receiving subcutaneous injection of L-thyroxine $(5 \mu \mathrm{g} / 100 \mathrm{~g}$ bwt/day $))(>)$ rats. Results are plotted as mean (SEM) representing at least eight animals.

deficient rats, ${ }^{+}$consequently the discussion will focus on comparisons made with the 240 IU vitamin A supplemented pair fed group 3. Group 4 was used as an additional control to investigate the impact of long term undernutrition based on the reduced food intake induced by vitamin $A$ deficiency. Group 5 provided a comparison of vitamin A deficiency with normal, conventional rats fed ad lib.

\section{BASAL AND SECRETAGOGUE INDUCED CHANGES}

IN ISC

The effects of vitamin A deficiency on colonic transport function were complex. It caused a significantly reduced basal Isc only in the distal colon when compared with pair fed vitamin A supplemented control rats (group 3). Studies with $\mathrm{Cl}^{-}$free buffers and furosemide, have shown that the major ionic component of the basal Isc in the distal colon in vitro from fed rats is the electrogenic secretion of $\mathrm{Cl}^{-}$ions (Nzegwu and Levin, unpublished results). In response to stimulation by the cholinergic secretory agonist, bethanechol, a significantly raised Isc secretory response was seen in the mid-colon of the vitamin A deficient rats (group 1) compared with the pair fed vitamin A supplemented control rats (group 3). In the distal colon, however, the response to bethanechol in the vitamin A deficient rats (group 1) was significantly reduced when compared with the pair fed control rats (group 3). The secretory Isc response to dibutyryl-cAMP in the proximal, mid, and distal colon was not significantly different between the vitamin A deficient and the 240 IU vitamin A supplemented control (group 3). Interestingly, secretagogues acting via cAMP mediation in the colon do not generate a hypersecretory response even in starvation and undernutrition, although bethanechol, a secretagogue acting via $\mathrm{Ca}^{++}$, does."
Two features of the secretory responses of the colon preparations to bethanechol and dibutyrylcAMP deserve mention. Firstly, it is clear that the time course of the development of the secretory current response for the two secretagogues is very different - that for bethanechol rapidly reaches a maximum and quickly decays while that for dibutyryl-cAMP slowly reaches a maximum and then gradually decreases. The probable reasons for these differences are as follows: (i) bethanechol, a stable muscarinic agonist, induces secretion via muscarinic receptors on the colonocytes by a transient increase in intracellular $\mathrm{Ca}^{++}$and receptor desensitisation also probably occurs, while (ii) dibutyryl-cAMP enters the colonocytes slowly to build up and maintain the intracellular levels of cAMP that activate secretion, a mechanism which obviously bypasses any receptors (see references $\left.{ }^{12}{ }^{13}\right)$. In addition, the various segments of the colon respond differently to the two secretagogues. The mid-colon gives the largest response for both. With bethanechol, the proximal segment is the next most responsive, and the distal the least. In the case of dibutyrylcAMP, however, the proximal and distal responses were not significantly different. The reasons for these differences are not fully understood. In the case of bethanechol, it could be partly due to variations in the density of the muscarinic receptors or their coupling to the secretory processes, but obviously this cannot occur with dibutyryl-cAMP. Other authors have also reported on the heterogeneity of response of the various segments of rat colon to secretagogues. ${ }^{131+}$

\section{CHANGES IN ELECTROGENIC NA ${ }^{+}$ABSORPTION}

In the ad lib fed conventional rats there is no, or very little, amiloride sensitive electrogenic $\mathrm{Na}^{+}$ absorption in the proximal, mid, or distal colon, in contrast to the $90 \%$ or more induced in the distal colon only by dietary $\mathrm{Na}^{+}$depletion. ${ }^{1516}$ This response is mediated by the increased plasma aldosterone value created by the lowered $\mathrm{NaCl}$ intake. We have recently shown that acute undernutrition (reducing the normal adult rat food intake by $33 \%$ to $8 \mathrm{~g} / \mathrm{rat} /$ day for up to nine days) induces a dramatic increase in the amiloride sensitive electrogenic $\mathrm{Na}^{+}$absorption in the rat distal colon.

The vitamin A deficient rats have a reduced food intake compared with that of rats fed diet CRM ad lib (group 5). In this respect, they can be regarded as chronically undernourished compared with normal fed rats. They were thus expected to show raised basal Isc and the amiloride induced reduction of this basal Isc, as demonstrated in the distal colon of CRM pair fed rats (group 4). In contrast, the basal Isc of the distal colon of the vitamin A deficient rats failed to respond to mucosal amiloride. Supplementing the vitamin A deficient rats with soluble vitamin $A$ in their drinking water allowed the induction of electrogenic $\mathrm{Na}^{+}$transport to appear in group 3 (viz, their increased basal Isc was significantly reduced by amiloride, Fig 3). One interpretation of this result is that vitamin A deficiency prevents the induction of amiloride sensitive, 


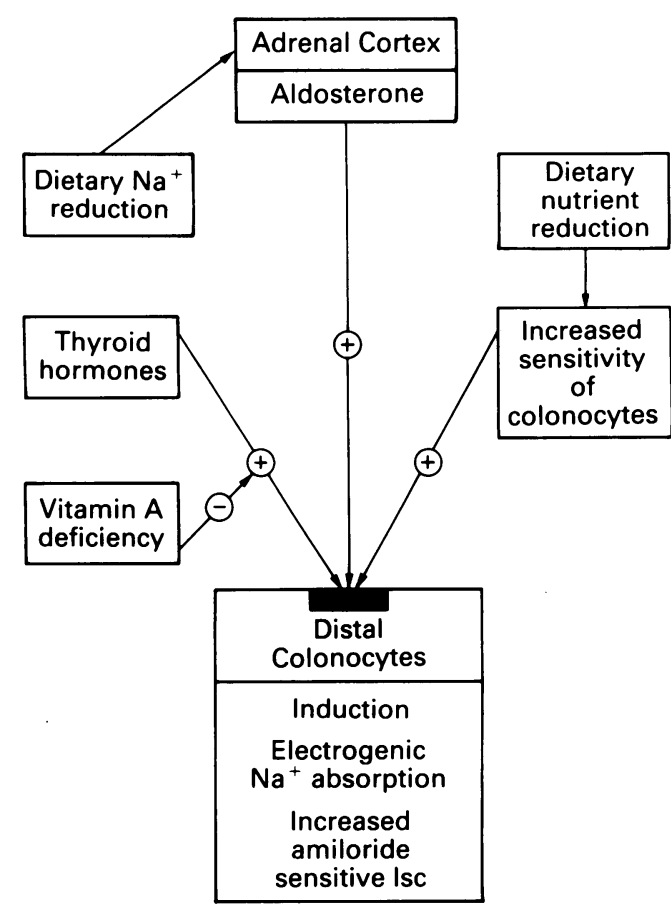

Figure 5: Schematic diagram of the possible inter-relations between diet, thyroid hormones, vitamin $A$, and aldosterone on the induction of electrogenic $N a^{\prime}$ absorption in rat distal colonocytes. (See text for details.)

electrogenic $\mathrm{Na}^{+}$absorption in the distal colon. The adaptive response of the distal colon to undernutrition (induction of amiloride inhibitable electrogenic $\mathrm{Na}^{+}$transport) is thus determined partly by the vitamin A status of the rats. In vitamin A deficiency, the distal colonocytes show a decreased response to aldosterone, which becomes partially restored by vitamin A supplementation. One obvious question that arises is what is the biochemical basis of this decreased response? Previous studies have shown that the thyroid hormones have a permissive effect on the acton of aldosterone on colonic functions. ${ }^{1017}$ Vitamin A deficiency is known to have a direct effect on the thyroid hormone status of rats. ${ }^{8918}$ Garcin and Higuret ${ }^{8}$ reported raised plasma levels of thyroxine and triiodothyronine in vitamin A deficient rats, while Higuret et al, ${ }^{9}$ found that in vitamin A deficient rats, there is a reduced functional capacity of nuclear triiodothyronine receptors, a reduced peripheral metabolism of thyroxine, and a reduced penetration of triiodothyronine into cells. All these findings are consistent with an apparent 'hyperthyroid status' of the thyroid hormones at the plasma level, but a 'hypothyroid state' at the peripheral cellular level.

We examined the involvement of the thyroid hormone in the distal colonic response to undernutrition in a group of conventional adult rats made hypothyroid. After acute undernutrition ( $8 \mathrm{~g} \mathrm{food} / \mathrm{rat}$ ) for nine days, the basal Isc of the distal colon of the hypothyroid rats was not only significantly reduced but did not respond to mucosal amiloride like that of the conventional, acutely undernourished rats. However, subcutaneous injection of L-thyroxine to the acutely undernourished rats which had been made hypothyroid restored the response to amiloride (Fig 4). These findings are consistent with studies by Edmonds and Wills, ${ }^{10}$ who reported that the hypothyroid condition in normally fed rats inhibited the induction of amiloride sensitive $\mathrm{Na}^{+}$transport in the distal colon.

The failure of the distal colon from vitamin A deficient rats to respond to their 'chronic undernutrition' could thus be due to the impaired action of thyroid hormones at the cellular level reported in this condition. ${ }^{8}$ A schematic summary of the putative links between vitamin A, the thyroid hormone, and nutritional status is given in Figure 5. Thompson and Edmonds ${ }^{1+}$ suggested that an impaired induction of ouabain sensitive ATPase may be responsible for the reduced colonic electrogenic $\mathrm{Na}^{+}$transport they observed in hypothyroidism. Other possibilities are changes in the aldosterone cytosolic receptor or an influence at the genome level. ${ }^{10} \mathrm{An}$ important recent discovery linking vitamin $A$ and the thyroid hormone is that the nuclear receptor for retinoic acid (vitamin $\mathrm{A})^{19}$ shows great homology with the DNA binding domain of the thyroid hormone receptor. Umesono et $a l^{20}$ concluded that retinoic acid and thyroid hormones, acting through their respective receptors, could control overlapping gene networks involved in the regulation of vertebrate morphogenesis and homeostasis. A study of human thyroid hormone levels in vitamin A deficiency and after treatment with vitamin A supplementation is obviously called for.

In conclusion, the results obtained in this study provide the first experimental evidence linking vitamin A deficiency with changes in colonic electrogenic absorptive and secretory functions. Enhancing the secretory response of the colon to cholinergic stimulation (bethanechol) and reducing the ability of the distal colon to absorb $\mathrm{Na}^{+}$electrogenically, possibly by mediation of thyroid hormones, together with the enhanced secretory activity of the ileum $^{+}$could be mechanisms whereby vitamin A deficiency tips the balance towards a diarrhoeal state as observed in humans. ${ }^{1321}$

Acknowledgement is given to the MRC for financial support.

1 Ramalingaswami V. Nutritional diarrhoea due to Vitamin A deficiency. Indian f Med Sci 1948; 11: 665-74.

2 Tilden EB, Miller EG. The response of the monkey (Macacus Rhesus) to withdrawal of Vitamin A from the diet. $\mathcal{F}$ Nutri 1930; 3: 121-40.

3 Feachem RG. Vitamin A deficiency and diarrhoea - a review of interrelationships and their implications for the control of interrelationships and their implications for the control of

Nzegwu Helen, Levin RJ. Vitamin A deficiency and smal intestinal secretory function in rat. Gut 1991; 32: 1324-8.
integend

5 Baldwin D, Levin RJ. Electrogenic currents induced by secretagogues and glucose across proximal and distal rat duodenum and jejunum in vitro. IRCS Med Sci 1985; 13: 269-70.

6 Theodorsson-Nordheim E. Kruskal-Wallis test: BASIC computer program to perform non-parametric one-way analysis of variance and multiple comparisons on ranks of analysis of variance and multiple comparisons on ranks of 1986; 23: 57-62.

7 Nzegwu Helen C, Levin RJ. Dietary restriction sensitises the distal rat colon to aldosterone. $\mathcal{F}$ Physiol (Lond) 1992; 447: 501-12.

8 Garcin $\mathrm{H}$, Higuret $\mathrm{P}$. Thyroid hormones in vitamin A deficient rats: effects of retinoic acid supplementation. Ann Nutr Metab 1983; 27: 495-500.

9 Higuret P, Paillen I, Garcin H. Vitamin A deficiency and triiodothyronine action at the cellular level in the rat. F Endocrinol 1989; 121 : 75-9.

10 Edmonds CJ, Wills CL. Aldosterone and thyroid hormone interaction on the sodium and potassium transport pathways of rat colonic epithelium. $\mathcal{F}$ Endocrinol $1990 ; 124: 47-52$.

11 Nzegwu Helen, Levin RJ. Dietary reduction increases secretion in rat distal colon induced by secretagogues acting via calcium but not by cyclic AMP. Proc Nutr Soc 1990;49: $178 \mathrm{~A}$. 
12 Young A, Levin RJ. Diarrhoea of famine and malnutrition: a rat model. 1. Jejunal hypersecretion induced by starvation. Gut 1990; 31: 43-53.

13 Nobles M, Diener M, Mestres P, Rummel W. Segmental heterogeneity of the rat colon in the response to activators of heterogeneity of the rat colon in the response to activators of
secretion on the cAMP-, the cGMP and the Ca' pathway. secretion on the cAMP-, the cGMP
Acta Physiol Scand 1991; 142: 375-86.

14 Young A, Levin RJ. Segmental heterogeneity of rat colonic electrogenic secretion in response to the bacterial enterotoxin E Coli Sta in vitro. Exp Physiol 1991; 76: 979-82.

15 Halevy J, Budinger ME, Hayslett JP, Binder HJ. Role of aldosterone in the regulation of sodium and chloride transport in the distal colon of sodium depleted rats. Gastroenterology 1986; 91: 1227-33.

16 Binder HJ, White A, Whiting D, Hayslett JP. Demonstration of specific high affinity receptors for aldosterone in cytosol of rat colon. Endocrinology 1986; 118: 628-31.
17 Thompson BD, Edmonds CJ. Aldosterone, sodium depletion and hypothyroidism on the ATPase activity of rat colonic epithelium. $\mathcal{F}$ Endocrinol 1974; 62: 489-96.

18 Morley JE, Damassa DA, Gordon I, Pekary AE, Hersham JM Thyroid function and Vitamin A deficiency. Life Sci 1978 . Thyroid function and Vitamin A deficiency. Life $S_{c t} 1978$

19 Anonymous. Retinoic acid and thyroid hormone regulate gene expression through a common gene element. Nutr Rev 1989 47: $332-4$

20 Umesono K, Giguere V, Glass CK, Rosenfeld MG, Evans RM. Retinoic acid and thyroid hormone induce gene expression through a common responsive element. Nature 1988; 336 : $262-5$.

21 West KP, Howard GR, Sommer A. Vitamin A and infection. Public Health Implications. Ann Rev Nutr 1989; 9: 63-86. 